\title{
A MUDANÇA PARADIGMÁTICA: COMO A MACROBIOÉTICA PODE AUXILIA̧R NA TRANSIÇÃO DO ANTROPOCÊNTRISMO PARA O ECOCENTRISMO
}

\section{A PARADIGM SHIFT: HOW MACROBIOETHICS CAN ASSIST IN THE TRANSITION FROM ANTHROPOCENTRISM TO ECOCENTRISM}

\author{
${ }^{1}$ Daniel Moura Borges
}

\begin{abstract}
RESUMO
A preservação ambiental não é feita com o objetivo de proteger o meio ambiente, mas para a proteção do próprio homem. Apesar de existirem instrumentos políticos e jurídicos que afirmam tratar da proteção ambiental, o que vemos, em verdade, é a instrumentalização da natureza em benefício da humanidade. O objetivo deste trabalho é demonstrar, de forma sucinta, como ocorreu a evolução histórica para o paradigma antropocêntrico, além de suas consequências sobre as políticas internacionais relativas ao meio ambiente. Será feito uma análise sobre os principais tratados internacionais envolvendo o meio ambiente, para demonstrar que, apesar de haver uma lógica antropocêntrica, há sinais, ainda que modestos, de que estamos chegando em um ponto de mudança. Com o surgimento dos novos temas do direito internacional, como foram chamados os temas abordados no pós-2 $2^{\text {a }}$ Guerra Mundial, minimizaram a quase exclusividade que a segurança e a economia tinham nos fóruns internacionais para haver um aumento nos debates relativos, por exemplo, às questões ambientais. Essa mudança de cunho político, associada ao surgimento de novas correntes filosóficas, está criando o ambiente favorável para que ocorra, provavelmente ainda no século em curso, uma mudança paradigmática que transforme a base teórica do antropocentrismo para o ecocentrismo, modificando a maneira como o homem se relaciona com ambiente no qual está inserido.
\end{abstract}

Palavras-chave: Direito, Meio ambiente, Macrobioética, Paradigma, Antropocentrismo, Ecocentrismo

\begin{abstract}
Environmental preservation is not made in order to protect the environment, but to the man's own protection. Although there are political and legal instruments to deal with the claim "environmental protection," what we see, in fact, it is the manipulation of nature for the benefit of humanity. The objective of this study is to demonstrate, succinctly, as was the historical evolution to the anthropocentric paradigm, and its consequences on international policies relating to the environment. We Will provide an analysis of the major international treaties involving the environment to demonstrate that, although there is an anthropocentric logic, there are signs, albeit modest, that we are coming to a point of change. With the emergence of "new issues" of international law, as the topics covered in the post- Second
\end{abstract}

1 Mestre em Direito pela Universidade Federal da Bahia. Professor no curso de Graduação em Direito da Universidade Federal da Bahia. Universidade Federal da Bahia - UFBA, Salvador - BA - Brasil

E-mail: danielsammet@yahoo.com.br 
World War were called, played down the almost exclusive that security and the economy had in international forums to be an increase in the discussions on, for example, environmental issues. This change of political nature, associated with the emergence of new philosophies, is creating a favorable environment to occur, probably even in the current century, a paradigm shift that transforms the theoretical basis of anthropocentrism to ecocentrism, modifying the way the man It relates to the environment in which it is inserted.

Keywords: Law, Environment, Macrobioethics, Paradigm, Anthropocentrism, Ecocentrism 


\section{INTRODUÇÃO}

A preservação ambiental não é feita com o objetivo de proteger o meio ambiente, mas para a proteção do próprio homem. Apesar de existirem instrumentos políticos e jurídicos que afirmam tratar da "proteção ambiental", o que vemos, em verdade, é a instrumentalização da natureza em benefício da humanidade.

O objetivo deste trabalho é demonstrar, de forma sucinta, como ocorreu a evolução histórica para o paradigma antropocêntrico, além de suas consequências sobre as políticas internacionais relativas ao meio ambiente.

Será feito uma análise sobre os principais tratados internacionais envolvendo o meio ambiente, para demonstrar que, apesar de haver uma lógica antropocêntrica, há sinais, ainda que modestos, de que estamos chegando em um ponto de mudança.

Com o surgimento dos "novos temas" do direito internacional ${ }^{1}$, como foram chamados os temas abordados no pós- $2^{\text {a }}$ Guerra Mundial, minimizaram a quase exclusividade que a segurança e a economia tinham nos fóruns internacionais para haver um aumento nos debates relativos, por exemplo, às questões ambientais.

Essa mudança de cunho político, associada ao surgimento de novas correntes filosóficas, está criando o ambiente favorável para que ocorra, provavelmente ainda no século em curso, uma mudança paradigmática que transforme a base teórica do antropocentrismo para o ecocentrismo, modificando a maneira como o homem se relaciona com ambiente no qual está inserido.

\section{EVOLUÇÃO HISTÓRICA DA PROTEÇÃO INTERNACIONAL AO MEIO AMBIENTE}

Com o fim da $2^{\text {a }}$ Guerra Mundial, a comunidade internacional pôde se concentrar em problemas que já haviam despontado, mas não pôde, por conta do conflito, serem confrontados

\footnotetext{
${ }^{1}$ Após a Segunda Guerra Mundial, houve um recuo na preocupação com temas de segurança e de economia internacionais. Não que eles tenham sido deixados de lado, mas após aquele evento histórico, temas relacionados, por exemplo, ao meio ambiente e ao desenvolvimento dos países em desenvolvimento passaram a ter, cada vez mais, destaque nos fóruns internacionais (GOMES, 1999, p.23-24).
}

(HOBSBAWM, 2010, p.257). A criação da Organização das Nações Unidas - ONU em abril 
de 1945, fruto da Conferência de São Francisco, possibilitou que esses temas fossem debatidos mais livremente pelos países que compunham a organização. A própria Carta das Nações Unidas, em seu artigo $1^{\circ}$, determina a multidisciplinariedade de objetivos da entidade ao elencar como propósitos da instituição a manutenção da paz e da segurança internacionais, promover relações amistosas entre seus membros, buscar a cooperação dos estados nos problemas de caráter econômico, social, cultural e humanitário e defender os direitos humanos e as liberdades fundamentais.

Esse posicionamento de harmonização do homem com a natureza coaduna-se com a doutrina denominada Geografia Crítica, que teve como expoente o geógrafo Milton Santos. Desenvolvida a partir da década de 1960, esse novo pensamento ia de encontro à forma positivista da geografia de observação do espaço e passava a enxergá-la por um viés mais crítico (MORAES, 2005, p. 128). Voltava o objeto de estudo da Geografia para a dimensão social do espaço e de que forma o homem se harmoniza com a natureza, bem como quais seriam os impactos negativos que o desequilíbrio dessa relação poderia causar (SANTOS, 1988, p.44).

Houve, de fato, grande mudança em relação à abordagem jurídica da temática ambiental, pois

Após as conferências de Estocolmo e do Rio de Janeiro, os tratados internacionais de direito ambiental adquiriram contornos próprios. Devido à natureza das obrigações e a peculiaridade dos bens ambientais protegidos, os tratados de direito ambiental assumiram características próprias e criaram mecanismos originais (ACCIOLY; SILVA; CASELLA,2012, p.697).

Com base na evolução dos fatos, pode-se notar um destaque maior dado ao princípio da solidariedade preconizado pela Revolução Francesa, levando, portanto, a uma leve relativização do antropocentrismo vigente. As novas teorias relativas ao princípio da solidariedade tendem a se preocupar, cada vez mais, com as condições humanitárias dos menos favorecidos e, indo além, passam a abarcar, além dos humanos, os demais seres vivos. É a solidariedade ambiental. Segundo Luiz Flávio Gomes:

Solidariedade é o ato de bondade com todas as pessoas, com a natureza e com os animais [...] A palavra solidariedade nos remete à ideia de que todos pertencemos a uma mesma comunidade, e que fazer a diferença para um de seus membros, significa melhorar o todo, ou seja, construir um mundo melhor (2013).

Por estar em constante mutação (BEZERRA, 2007, p.244), é perfeitamente cabível a aplicação do princípio da solidariedade para os demais seres que coabitam o planeta com o homem. Este é um conceito elástico, que deve ser sempre aplicado no melhor interesse, não apenas do ser humano, mas de toda a biosfera.

Cada vez mais, está presente a noção de que o homem está harmoniosamente inserido em um 
meio diversificado e não em uma posição de supremacia em relação à natureza que está ao seu redor. Mesmo não sendo esse, ainda, o pensamento preponderante,

\footnotetext{
Mais cedo ou mais tarde, porém, os homens haverão de admitir as demais espécies como integrantes da comunidade ética, ao menos aqueles que conseguirem sobreviver ao verdadeiro genocídio a que vêmsendo submetidas, quer seja através da destruição do seu habitat natural ou simplesmente pelo seu extermínio [...] (GORDILHO, 2011, p.124).
}

Diante desta tendência, novos instrumentos normativos internacionais foram produzidos, levando em conta a preocupação das organizações internacionais com a qualidade de vida do homem, indo além.

Se é verdade que algumas práticas contemporâneas, como o consumo predatório, desperdício e má alocação de recursos tendem a prejudicar, não apenas o desenvolvimento humano, mas, também, o equilíbrio ecológico, começa a surgir o questionamento de tais práticas, tanto na sociedade civil, quanto pelas autoridades internacionais.

Refletindo essa nova realidade do pós-guerra e da mudança de consciência social sobre a matéria, foram elaborados tratados, pactos e protocolos ${ }^{2}$ que têm como objetivo a assunção, por parte dos estados signatários, o compromisso de garantir o equilíbrio ecológico, a biodiversidade e a observância de princípios bioéticos.

\subsection{DECLARAÇÃO UNIVERSAL SOBRE BIOÉTICA E DIREITOS HUMANOS}

Logo após a criação da ONU, diante da necessidade de difundir a cultura e a educação, promover o desenvolvimento ético das ciências, ainda em 1945, criou-se a Organização das Nações Unidas para a Educação Ciência e a Cultura - UNESCO (2012). A criação dessa organização independente, apesar de vinculada à ONU, visa, através dessas três áreas de sua competência, desenvolver a paz "de dentro para fora”, ou seja, usar a educação, a ciência e a cultura, elementos absorvidos pela mente humana, para projetar uma cultura de paz para o exterior, através de projetos e ações.

\footnotetext{
2 Os tratados, acordos escritos realizados entre dois ou mais estados, é um termo genérico. As diversas nomenclaturas a ele associados, como pactos e protocolos, por exemplo, servem para determinar características específicas para cada acordo. Pacto é um termo comumente utilizado para acordos com forte conteúdo político envolvido. Já protocolo, por sua vez, costuma ser relacionado a um acordo subsidiário.
}

A mobilização pela educação, a construção do conhecimento intercultural, a busca pela 
cooperação científica, a proteção pela liberdade de expressão, a garantia da preservação ambiental, e a proteção da participação democrática são os objetivos primordiais da UNESCO (2015).

Como a proteção do homem, da natureza e da sua relação constam dos objetivos da organização, em 2005, durante a $33^{\text {a }}$ Conferência Geral da UNESCO, foi adotada, pela primeira vez, uma declaração explícita sobre bioética. A Declaração Universal sobre Bioética e Direitos Humanos condensou, em um único texto, os princípios através dos quais as questões éticas são associadas à vida humana. Há uma associação da ética, sobretudo relacionada às ciências médicas e da vida, com a dignidade humana.

Apesar da louvável iniciativa em condensar diversos temas relacionados à bioética em um único texto de abrangência internacional, percebemos que, mesmo diante das crescentes preocupações ambientais, o paradigma antropocêntrico ainda impera.

Em diversas passagens da Declaração percebemos uma preocupação maior com a proteção do homem do que do meio ambiente em si. A dignidade humana deve ser preservada, até porque o homem faz parte do ambiente no qual está inserido. Mas os interesses das formas de vida não humanas parecem não receber a mesma proteção, num contexto em que, para que haja uma ética plena da vida, não é possível tal segregação.

Apesar de fazer importantes considerações sobre a proteção da vida humana e do desenvolvimento científico em prol do seu bem-estar, a biodiversidade tem sua importância associada diretamente ao desenvolvimento humano. A Declaração faz questão de "sublinhar a importância da biodiversidade e da sua preservação enquanto preocupação comum à humanidade" (UNESCO, 2006), mas este é apenas um dos oito objetivos explícitos pelo documento. Fora passagens pontuais, como a citada, em que a proteção ambiental é mencionada como fim da declaração, a preocupação com a dignidade e liberdade humanas parecem prevalecer, deixando subentendido que o propósito real do documento foi abordar as questões de microbioética, diretamente associadas ao interesse individual. O próprio título do documento sugere esse posicionamento ao deixar expresso que é uma declaração universal sobre bioética e "Direitos Humanos".

\subsection{CONVENÇÃO DAS NAÇÕES UNIDAS SOBRE DIVERSIDADE BIOLÓGICA}


Apesar da preocupação ambiental implícita na carta constitutiva da UNESCO, havia, ainda, a necessidade de que fosse criado um instrumento internacional que abarcasse exclusivamente as questões ambientais.

O meio ambiente começou a ter relevo nos debates internacionais através da Conferência sobre a Biosfera realizada em Paris, em 1968. Tal conferência, organizada pela Organização das Nações Unidas, para a Educação, a Ciência e a Cultura - UNESCO, colocou em pauta a relação direta que existe entre o homem e a natureza, e como o dano sofrido por ela atinge, diretamente, o ser humano. Especialistas de diversas áreas abordaram, principalmente, a poluição atmosférica e o fenômeno da chuva ácida. Como decorrência desse evento, propõe-se, no final da década de sessenta do século XX, a realização de uma grande conferência sobre meio ambiente, que não fosse limitada apenas pelo aspecto científico, mas que tratasse de temas diretamente correlatos, como as questões sociais e econômicas.

Em 1972, é realizada a Conferência das Nações Unidas sobre Meio Ambiente Humano UNCME, em Estocolmo, na Suécia. Esta conferência pode ser considerada um marco na proteção ambiental internacional, pois, diferentemente das anteriores, não se restringiu ao ambiente científico, mas acrescentou ao debate os estados, as organizações internacionais e setores da sociedade civil organizada, como Organizações Não-Governamentais - ONG's voltadas à proteção do Meio Ambiente. Desta maneira, “[...] a questão do meio ambiente foi transferida para um contexto muito mais amplo, com importantes ramificações nas áreas política, econômica e social” (LAGO, 2007, p.17)

Além da maior participação da comunidade internacional, a referida conferência serviu para consagrar o debate ambiental, além de associar o bem-estar social ao equilíbrio ambiental. A Declaração de Estocolmo ${ }^{3}$ proclama que:

\footnotetext{
3 Disponível em: < http://www.onu.org.br/rio20/img/2012/01/estocolmo1972.pdf>. Acesso em 23 nov. 2013.
} 
O homem é ao mesmo tempo obra e construtor do meio ambiente que o cerca, o qual lhe dá sustento material e lhe oferece oportunidade para desenvolver-se intelectual, moral, social e espiritualmente [...] Chegamos a um momento da história em que devemos orientar nossos atos em todo o mundo com particular atenção às consequências que podem ter para o meio ambiente. Por ignorância ou indiferença, podemos causar danos imensos e irreparáveis ao meio ambiente da terra do qual dependem nossa vida e nosso bem-estar. Ao contrário, com um conhecimento mais profundo e uma ação mais prudente, podemos conseguir para nós mesmos e para nossa posteridade, condições melhores de vida, em um meio ambiente mais de acordo com as necessidades e aspirações do homem.

Como consequência do destaque que a temática ambiental ganhou nos anos anteriores, a ONU criou em 1973 um mecanismo permanente para tratar do tema, o Programa das Nações Unidas Para o Meio Ambiente - PNUMA. Pela primeira vez, tinha-se, no seio das nações unidas, um local apropriado para serem realizados debates permanentes sobre o meio ambiente.

Atribui-se, ainda, à UNCME o início da criação do termo “desenvolvimento sustentável”, pois Maurice Strong, então Secretário Geral da Conferência, defendeu no evento a promoção do ecodesenvolvimento (MONTIBELLER FILHO, 1993, p.102). Este conceito tem semelhanças com o de desenvolvimento sustentável, mas um antecede ao outro, apresentando certas diferenças, principalmente na cronologia da abordagem entre desenvolvimento e meio ambiente. Enquanto o desenvolvimento sustentável prega uma evolução conjunta e paralela da economia, do desenvolvimento e da preservação ambiental, o ecodesenvolvimento, por sua vez, propunha, num primeiro momento, a solução dos problemas ambientais para, apenas posteriormente, solucionar os problemas relativos ao desenvolvimento. Desentendimentos entre os países desenvolvidos e em desenvolvimento inviabilizaram a implementação do ecodesenvolvimento, abrindo margem para o reforço do conceito de desenvolvimento sustentável, criado pela Comissão Mundial sobre o Meio Ambiente e Desenvolvimento e publicado em 1987 no relatório intitulado "Nosso Futuro Comum".

Realizou-se no Rio de Janeiro, em 1992, a Conferência das Nações Unidas sobre o Meio Ambiente e o Desenvolvimento - CNUMAD, popularmente conhecida como "Rio92". Nesta conferência o conceito de Desenvolvimento Sustentável foi solidificado e popularizado ${ }^{4}$. Findou-se, também, o processo iniciado em Estocolmo de participação popular nos debates ambientais. Os cientistas, através de pesquisas, os estados, através de acordos e financiamentos

\footnotetext{
4 O relatório da ONU intitulado Agenda XXI já expunha o termo desde seu preâmbulo. O documento afirma que “[...] Não obstante, caso se integrem as preocupações relativas a meio ambiente e desenvolvimento e a elas se dedique mais atenção, será possível satisfazer às necessidades básicas, elevar o nível da vida de todos, obter ecossistemas melhor protegidos e gerenciados e construir um futuro mais próspero e seguro. São metas que nação alguma pode atingir sozinha; juntos, porém, podemos - em uma associação mundial em prol do desenvolvimento sustentável. Disponível em: < http://www.onu.org.br/rio20/img/2012/01/agenda21.pdf> Acesso em 23 nov. 2013.
} 
e as $\mathrm{ONG}^{\text {s, }}$, sobretudo através do Fórum Global, passaram a fazer parte da base do debate ambiental internacional. Desta convenção, cinco documentos foram aprovados. São eles: a Agenda XXI, a Declaração do Rio, a Declaração de Princípios sobre Florestas, a Convençãoquadro sobre Mudanças Climáticas e a Convenção-quadro sobre biodiversidade.

Houve, de fato, grande mudança em relação à abordagem jurídica da temática ambiental, pois

Após as conferências de Estocolmo e do Rio de Janeiro, os tratados internacionais de direito ambiental adquiriram contornos próprios. Devido à natureza das obrigações e a peculiaridade dos bens ambientais protegidos, os tratados de direito ambiental assumiram características próprias e criaram mecanismos originais (ACCIOLY; SILVA; CASELLA,2012, p.697).

Ainda que abordando especificamente a temática da tutela jurídica ambiental, percebemos uma forte conexão entre a mesma e o desenvolvimento humano. O próprio título da conferência demonstra isso, já que é uma reunião que teve como objetivo tratar das questões referentes ao "meio ambiente e ao desenvolvimento". Seguindo a lógica proposta pela conferência, a Convenção das Nações Unidas sobre Diversidade Biológica - CBD, criada no seio da CNUMAD, tem como objetivos a conservação da diversidade biológica, a sua utilização sustentável, bem como a repartição equitativa dos benefícios advindos de sua exploração (UN, 1992, p.3).

Apesar da presente convenção se referir, apenas, à diversidade biológica, observamos, já em seus objetivos, que a CDB também vincula diretamente a proteção ambiental, no caso específico da biodiversidade, ao bem-estar humano. A preservação da biodiversidade não é apresentada como um fim em si mesmo, mas, também, como diretamente relacionada à sua exploração e ao desenvolvimento humano.

\subsection{CÚPULA MUNDIAL SOBRE DESENVOLVIMENTO SUSTENTÁVEL}

10 anos após a realização da Rio92, em 2002, ocorreu, na África do Sul, a Cúpula Mundial sobre Desenvolvimento Sustentável, também conhecida como Cúpula de Joanesburgo, que

[...] foi convocada, por sua vez, comvistas a estabelecer um plano de implementação que acelerasse e fortalecesse a aplicação dos princípios aprovados no Rio de Janeiro. A década que separa as duas conferências confirmou o diagnóstico feito em 1992 e a dificuldade de implementar suas recomendações (LAGO, 2007, p.18).

Apesar de referir-se, explicitamente, ao desenvolvimento sustentável, conforme citação supra, a ideia primordial da reunião seria debater e encontrar formas de implementar, mais eficazmente, as políticas adotadas pela Rio92. Talvez pelo fato do conceito de desenvolvimento 
ter ganhado força no Rio, além de ter ganhado força na sociedade civil, esse termo tenha sido escolhido para dar nome à cúpula. Segundo o então secretário geral da ONU Kofi Annan (2002), At its core, Johannesburg is about the relationship between human society and the natural environment ${ }^{5}$.

Sendo assim, não foi apenas uma reunião sobre desenvolvimento sustentável, mas sobre todos os tópicos abordados pela CNUMAD, dentre eles a preservação da biodiversidade e da garantia de seu equilíbrio.

\subsection{CONFERÊNCIA DAS NAÇÕES UNIDAS SOBRE DESENVOLVIMENTO SUSTENTÁVEL}

Em junho de 2012, a Conferência das Nações Unidas sobre Desenvolvimento Sustentável, intitulada "RIO+20", além de verificar se os princípios preconizados na primeira reunião estavam sendo obedecidos, reafirmou a importância da conservação ambiental e de sua abordagem multilateral, além da tendência de participação da sociedade civil. Ao revelar a doutrina da ONU sobre o tema, o relatório "O Futuro que Queremos”, produto desta conferência

[...] renova nosso compromisso com o desenvolvimento sustentável e com a garantia de um futuro econômico, social e ambientalmente sustentável para nosso planeta e para as futuras gerações [...] Nós reafirmamos que continuamos sendo guiados pelos propósitos e princípios da Carta das Nações Unidas, com total respeito ao Direito Internacional e a seus princípios. Nós ainda reafirmamos a importância da liberdade, da paz e da segurança[... $]^{6}$ (tradução nossa)

O Secretário-Geral das Nações Unidas, Ban Ki-moon, comentando os resultados da RIO+20, em discurso na Assembleia Geral da ONU em julho de 2012, reafirmou a importância da participação popular nas discussões ambientais ao afirmar que "os governos permanecem no centro. Mas sabemos que os governos sozinhos não podem fazer o trabalho. Precisamos da participação ativa e apoio de todos os principais grupos da sociedade civil, incluindo o setor privado" (MOON, 2012).

\footnotetext{
5 A questão central da Cúpula de Johanesburgo é o relacionamento entre a sociedade humana e o meio ambiente natural (tradução nossa).

6 [...] renew our commitment to sustainable development and to ensuring the promotion of an economically, socially and environmentally sustainable future for our planet and for present and future generations [...]We affirm that we continue to be guided by the purposes and principles of the Charter of the United Nations, with full respect for international law and its principles. We also reaffirm the importance of freedom, peace and security [...] Disponível em: <http://www.rio20.gov.br/documentos/documentos-da-conferencia/o-futuro-quequeremos/at_download/the-future-we-want.pdf>. Acesso em 17. Nov. 2013.
} 


\subsection{CONFERÊNCIA DAS NAÇÕES UNIDAS SOBRE DESENVOLVIMENTO SUSTENTÁVEL}

Em junho de 2012, a Conferência das Nações Unidas sobre Desenvolvimento Sustentável, intitulada "RIO+20", além de verificar se os princípios preconizados na primeira reunião estavam sendo obedecidos, reafirmou a importância da conservação ambiental e de sua abordagem multilateral, além da tendência de participação da sociedade civil. Ao revelar a doutrina da ONU sobre o tema, o relatório “O Futuro que Queremos”, produto desta conferência

[...] renova nosso compromisso com o desenvolvimento sustentável e com a garantia de um futuro econômico, social e ambientalmente sustentável para nosso planeta e para as futuras gerações [...] Nós reafirmamos que continuamos sendo guiados pelos propósitos e princípios da Carta das Nações Unidas, com total respeito ao Direito Internacional e a seus princípios. Nós ainda reafirmamos a importância da liberdade, da paz e da segurança[...] $]^{6}$ (tradução nossa)

O Secretário-Geral das Nações Unidas, Ban Ki-moon, comentando os resultados da RIO+20, em discurso na Assembleia Geral da ONU em julho de 2012, reafirmou a importância da participação popular nas discussões ambientais ao afirmar que "os governos permanecem no centro. Mas sabemos que os governos sozinhos não podem fazer o trabalho. Precisamos da participação ativa e apoio de todos os principais grupos da sociedade civil, incluindo o setor privado" (MOON, 2012).

Percebemos a grande preocupação com o conceito de desenvolvimento sustentável, bem como a difusão que o tema obteve nos últimos vinte anos, reforçando a necessidade de uma convivência harmoniosa entre o homem e a natureza.

\subsection{CRÍticas AO MODELO APRESENTADO PELAS CONFERÊNCIAS INTERNACIONAIS}

Percebemos, muitas vezes, que o modelo apresentado pelas conferências internacionais é limitado. Sobretudo porque visa, na maioria das vezes, atender, direta ou indiretamente, os interesses humanos.

Não questionamos a necessidade de fomentar o desenvolvimento humano, desde que a proteção da biodiversidade tenha o mesmo destaque. Entendemos que a relação harmoniosa do homem com a natureza pode ser o grande responsável para realização deste intento. O problema se apresenta quando o desenvolvimento humano é priorizado em convenções fundadas com o objetivo de preservação do meio ambiente e da biodiversidade. 
Em linhas gerais, pelo próprio título da conferência, era esperado que o tema do desenvolvimento humano tivesse destaque na CNUMAD, mas a partir do momento em que foi criada uma Convenção específica sobre diversidade biológica, imaginava-se que, ao menos nas discussões realizadas no âmbito deste Tratado, a proteção à biodiversidade fosse um fim em si mesmo. Na realidade, podemos constatar que a Convenção da Diversidade Biológica tenta garantir a proteção da diversidade biológica apenas como um recurso humano, uma reserva a ser explorada, uma vez que tem, entre seus objetivos, garantir o uso sustentável e a justa repartição dos benefícios genéticos ${ }^{7}$.

Mas, essa visão antropocêntrica da preservação ambiental não ficou restrita à Convenção da Diversidade Biológica. As duas últimas grandes conferências internacionais sobre meio ambiente, a Cúpula de Joanesburgo e a Rio+20, tiveram como objetivo central a abordagem de questões relacionadas ao desenvolvimento sustentável. A abordagem inicial da Eco92 era muito mais completa, uma vez que, além do desenvolvimento sustentável, abordava, explicitamente, questões como a preservação da biota. Podemos observar que o interesse da preservação ambiental como uma finalidade própria foi sendo substituída, cada vez mais, pela preservação como meio de garantir a sobrevivência e o desenvolvimento humanos.

\section{A CONSTRUÇÃO DO ANTROPOCENTRISMO}

No período pré-socrático, o pensamento humano se caracterizava por conter fortes traços místicos (PELIZZOLI, 1999, p.49). Por ser produto da construção humana, o Direito também continha fortes traços místicos. Se a sociedade era regida por esses parâmetros, era de se esperar que o controle social estivesse embasado em pensamentos fortemente atrelados à natureza, uma vez que o homem tinha desenvolvido apenas controles rudimentares sobre os fatos naturais.

\footnotetext{
7 The objectives of this Convention, to be pursued in accordance with its relevant provisions, are the conservation of biological diversity, the sustainable use of its components and the fair and equitable sharing of the benefits arising out of the utilization of genetic resources, including by appropriate access to genetic resources and by appropriate transfer of relevant technologies, taking into account all rights over those resources and to technologies, and by appropriate funding. Disponívelem: < https://www.cbd.int/convention/articles/default.shtml?a=cbd-01>. Acesso em: 16 mai.2015.
} 
Este controle se restringia, basicamente, à utilização de técnicas de cultivo agropastoril. Por ter a percepção de que a natureza era a grande força que regia o universo, os Deuses eram fortemente atrelados a elementos naturais e a explicação para os acontecimentos naturais eram atribuídos às entidades correspondentes aos diversos eventos naturais como, por exemplo, a vinculação das tempestades a Zeus. Ao agradá-lo, evitar-se-iam catástrofes relacionadas a esse evento natural, como inundações, por exemplo.

Como a natureza era a grande força conhecida e como os Deuses eram tidos como os controladores dessa forca, o pensamento humano, dentre eles o Direito, era fortemente embasado no caráter místico e no respeito à natureza. Diferentemente da modernidade, e da pósmodernidade até o presente momento, em que o racionalismo embasa as condutas sociais e as descobertas científicas, na antiguidade, o misticismo fornecia explicações satisfatórias para a época sobre os eventos naturais, bem como de que forma as condutas sociais deveriam ser reguladas.

Ao aplicar a razão aos fatos da natureza, os filósofos pré-socráticos tentaram demonstrar a importância dos elementos naturais para a constituição e para a existência humanas. Passou-se a conferir uma explicação racional ao mundo. Ao menos entre os pensadores, iniciou-se um processo de conferir às interações naturais a explicações para diversos fenômenos naturais e comportamentos humanos. Tornou-se insuficiente atribuir aos deuses a responsabilidade por esses eventos.

Para ilustrar essa transição, podemos analisar os estudos de Tales de Mileto. Ao tentar encontrar um elo entre todas as coisas, ele chegou à conclusão de que tudo o que existe é composto por água (BARRETO, 2011, p.17). Assim, a presença desse elemento em todas as coisas comprovaria muitos dos eventos e interações que ocorrem entre o homem e o meio em que está inserido, além de explicar uma serie de fenômenos naturais. Sendo assim, os filósofos présocráticos, apesar de manterem suas teorias baseadas nos elementos da natureza, não o fazem de forma mística. Procuram demonstrar racionalmente a existência desse vínculo.

Aristóteles faz uso dessa lógica empirista herdada dos pré-socráticos e adiciona a razão humana como forma de explicar as coisas e suas relações com o homem, bem como as relações sociais. Ele "já é um classificador do real, criador da lógica e um superador dos mitos; faz uma 'ciência racional da natureza"” (PELIZZOLI, 2004, p.59).

Em sentido oposto, Platão prega a separação entre a razão e o conhecimento empírico. Para ele 
aquele seria superior a este, devendo o homem fazer uso exclusivamente da razão para explicar as regras sociais e naturais (CERVI, 2012, p.11). O filosofo faz a separação da razão da natureza animalesca do homem, declarando a superioridade daquela.

Após Cristo, que foi responsável pela ascensão do modelo da alteridade na história da humanidade, a Igreja fundada por Pedro optou pela adoção de um modelo hierárquico baseado no arquétipo patriarcal vigente antes de Cristo (BYINGTON, 2008, p.267-268). Como dito, a Igreja Católica, através de seus "Doutores”, aplicou o conceito de superioridade da razão (alma) trazido por Platão e estabeleceu um corpo hierárquico fundado no modelo patriarcal. Modelo este que, mesmo apesar das reformas religiosas, como o Protestantismo de Lutero no século XVI, e político-filosóficas, como o Renascentismo e o Iluminismo, permanecem como paradigmas da cultura e do pensamento ocidentais.

Mas, o arquétipo patriarcal não pode ser considerado como uma característica apenas da Igreja Católica. O Islã, o Judaísmo e o Cristianismo em todas as suas vertentes possuem uma origem em comum. Além de terem como dogma a crença em apenas um Deus, originam-se das visões conferidas por Deus ao profeta Abraão, por isso são conhecidas como religiões Abraâmicas (MUNIR, 2013, p.45). Dentre os diversos pontos em comum, as religiões monoteístas promoveram o afastamento do homem da religião. Apesar dessa afirmação, em princípio, parecer contraditória, uma análise um pouco mais apurada a torna compreensível.

O monoteísmo, diferentemente das religiões politeístas, promoveu o distanciamento do homem das entidades divinas. Outrora, os Deuses "caminhavam entre os homens", ou seja, apesar de conservarem sua divindade, constantemente conviviam com os humanos neste planeta, muitas vezes, inclusive, interagindo através de relações sociais e amorosas e partilhando de suas dores e prazeres. A partir do momento em que uma entidade superior foi erigida à condição de Deus único, automaticamente, esse Deus passou a não compartilhar o convívio próximo aos homens. Coube a esse Deus, basicamente, criar todas as coisas e fazer as regras através das quais os homens serão julgados no momento de sua morte.

Durante o período em que está na terra, o homem deveria usar das qualidades que Deus os concedeu para solucionar os problemas e superar as adversidades que fossem surgindo (BOLTON, 2010, p.26). Nesse processo, houve a colocação do conhecimento científico, sobretudo das ciências duras, num patamar de superioridade em relação aos demais saberes, como a moral e a ética. Como a religião, ainda que institucionalizada, aborda, basicamente, esses dois temas, afirmamos que a teologia monoteísta incentivou a separação do homem da 
religião e, de certa forma, dos preceitos éticos e morais pregados por ela.

Foi esse cenário que proporcionou a Descartes a possibilidade de lecionar que a razão pura é o padrão a ser adotado em qualquer estudo. Esse posicionamento permitiu ao estudioso, por exemplo, realizar vivissecções em animais no Convento de Port-Royal (SANTANA, 2006, p.52) já que eles não passariam de máquinas (DESCARTES, 2001, p.63), pois eram desprovidos da razão (SIMÕES et al, 2011, p.26).

Algumas correntes modernas contestaram a doutrina de Descartes. O Panteísmo, contrariamente ao dualismo, cartesiano pregava a unidade entre a alma (razão) e o corpo; entre Deus e a natureza (SPINOZA, 2009. P.12). Leibniz também discorda de Descartes em alguns pontos. Dentre eles, destacamos o fato de que, para este autor os animais também teriam almas indestrutíveis como a nossa, mas que a racionalidade humana superaria qualitativamente as dos demais seres (PAIXÃO, 2001, p.52).

Apesar de alguns pensamentos modernos contrários, o cartesianismo dualista prosperou. Segundo ele, a razão era dissociada do corpo, sendo coisas diferentes. Por ser portador da razão, diferentemente dos demais seres vivos, o homem seria superior aos demais animais.

Com a ascensão do capitalismo globalizado ${ }^{8}$, pregando massivamente através da mídia (GARRAFA; PORTO, 2003, p.35) o culto ao consumismo, o antropocentrismo teria evoluído para um egocentrismo, uma espécie de antropocentrismo através do qual não há, apenas, a noção de superioridade do homem em relação à biosfera, mas o egoísmo em relação aos outros humanos. Os desejos individuais superficiais teriam sido alçados a um patamar mais elevado do que o bem-estar social.

\footnotetext{
8 Ressaltamos que não compartilhamos da opinião de autores que, como Simony Lopes da Silva Reis (2015, p.373- 374), que atribuem exclusivamente os danos ambientais ao sistema econômico capitalista. Tratamos do dano causado pelo capitalismo globalizado, não por considerar este o único modelo econômico poluidor, uma vez que o comunismo praticado pela URSS, por exemplo, também causou graves danos ambientais, como a poluição do Mar de Aral (posso citar livro que contesta o socialismo). Nós frisamos a globalização por uma questão de contextualização, já que o socialismo não prospera atualmente em qualquer país economicamente relevante, então os maiores danos ambientais atuais serão encontrados em países associados ao capital globalizado. Não acreditamos que exista um modelo econômico mais poluente, uma vez que todos eles são antropocentristas. O destaque feito ao capitalismo global é meramente pelo fato de ter sido o modelo que ganhou mais relevância nas últimas décadas. Sobre a desertificação do Mar de Aral:

< http://planetasustentavel.abril.com.br/noticia/ambiente/conteudo_345576.shtml>. Acesso em: 16 mai.2015.
}

O humano enfrenta seu estado de necessidade e precariedade de várias maneiras, inclusive com o saber-fazer racional e operacional da tecnociência. Ademais, neste 
século adquiriu a competência biotecnocientífica, que visa transformar e reprogramar o ambiente natural, os outros seres vivos e a si mesmo em função de seus projetos e desejos, fato que se torna, cada vez mais, motivo de grandes esperanças e angústias, consensos e conflitos, em particular do tipo moral (SCHRAMM).

Essa característica egocêntrica é tão marcante que o tema relacionado ao meio ambiente mais comumente debatido é o desenvolvimento sustentável. Quando falamos em desenvolvimento sustentável, o seu conteúdo econômico fica evidente. Ao falar em desenvolvimento sustentável, vemos em primeiro lugar a preocupação estatal com o próprio desenvolvimento econômico, redução do risco-país, elevação do PIB, etc. Depois um crescimento das receitas líquidas do setor industrial e financeiro, como as obtidas ao receber isenções tributárias ao utilizar tecnologias "verdes", por exemplo. Isso explicaria a variedade de fóruns associados ao tema e a escassez de debates referentes à macrobioética. A ética parece ser deliberadamente excluída dos debates pois pode demonstrar quais são os pontos mais críticos associados ao desequilíbrio e a poluição ambientais, apresentar soluções alternativas ao problema, como a implementação de sistemas de saneamento básico eficientes, por exemplo.

Passar por um processo de desenvolvimento deve ir além do critério meramente econômico (POMPEU; HOLANDA, 2014, p.236-237) e deve sopesar a relação custo-benefício dos empreendimentos potencialmente impactantes ao meio ambiente, bem como quais políticas adotar para a sua recuperação. É preciso garantir nesse processo o que V. R. Potter chamou de "sobrevivência aceitável" dos sujeitos hipossuficientes, que provavelmente serão os mais afetados perante eventual degradação ambiental. Ou seja, diante das alterações de ordem ambiental, deve ser proporcionado proporcionar da maneira mais eficaz possível uma forma de vida adequada, notadamente através da dignidade humana e do direito à saúde (POTTER; POTTER, 1995, p.3)

Percebemos uma preterição da ética em favor do racionalismo cartesiano moderno. O destaque conferido ao método científico rigoroso, construído com base na metodologia aplicada às "ciências duras" promoveram um distanciamento entre o desenvolvimento científico e a análise moral de suas consequências. Talvez essa seja o grande próximo passo do conhecimento humano; diminuir essa distância e fazer a análise ética das descobertas científicas acompanhar sua evolução técnica. O despertar para essas questões pode demonstrar que o paradigma antropocêntrico atual está ultrapassado e que deve surgir um novo que seja mais adequado as novas necessidades do homem, dos demais seres e do ambiente no qual estão inseridos. 


\section{O CAMINHO PARA A CONSTRUÇÃO DO PARADIGMA ECOLÓGICO}

Diante da percepção de que o antropocentrismo tem se mostrado insuficiente para a defesa do planeta, começam a surgir novas correntes filosóficas que apontam para um processo de mudança de paradigma. Essas correntes são minoritárias e ainda não ganharam força suficiente para chegar ao ápice da grande mudança paradigmática, mas é certo que o despertar da consciência ecológica e da inserção do homem em um ambiente vivo são um caminho para essa realização. É por isso que cada vez mais novos estudos são realizados envolvendo temas relacionados ao meio ambiente. Novas correntes vêm surgindo, ganhando cada vez mais adeptos. Apesar da grande diversidade de correntes teóricas, optamos por escolher as que mais têm se destacado e que impulsionam a consciência coletiva para uma mudança do paradigma antropocêntrico para o ecocêntrico.

\subsection{TEORIAS ANIMALISTAS}

Seja por conta de argumentos bem fundamentados ${ }^{9}$, seja pelos atos de vandalismo cometidos por correntes mais radicais ${ }^{10}$, os abolicionistas e bem-estaristas vêm ganhando cada vez mais espaço na mídia e nos meios acadêmicos. Apesar das divergências, ambos concordam em pelo menos um ponto; é preciso melhorar a condição animal.

\footnotetext{
${ }^{9}$ A exemplo dos doutrinadores citados neste item.

${ }^{10}$ Como a invasão e destruição de laboratórios que utilizam animais não humanos em pesquisas por exemplo.
}

Para os abolicionistas, o uso dos animais para o entretenimento, para a alimentação e para o vestuário deve cessar, uma vez que existem outros meios para suprir tais necessidades. Pensar 
diferente seria especismo" 11 algo como um "racismo" entre espécies, ou seja, nesse caso, a crença da superioridade humana sobre os outros animais. "Além de um lado inclusivo, onde todos os membros de uma espécie são considerados iguais dentro da comunidade moral, a ética especista possui um lado excludente, que postula que apenas os integrantes de uma única espécie devem ser considerados iguais" (SANTANA, 2006, p.48).

Por conta do desenvolvimento tecnológico atual, o ser humano poderia viver tranquilamente alimentando-se a base de produtos vegetais ricos em proteínas e substitutivos da carne, como a soja, preferir utensílios confeccionados em material sintético no lugar do couro, além de abolir apresentações que utilizem animais como atrações, como é o caso dos circos e rodeios. A carne animal, atualmente, seria consumida como um luxo, pelo sabor do alimento, não por uma questão de necessidade (SINGER, 1993, p.43).

Apesar desse ponto em comum entre abolicionistas e benestaristas, até por serem utilitaristas, há divergências entre os autores sobre a extensão dos direitos dos animais e sobre a forma ideal para uma mudança de consciência social.

To be a utilitarian means that you judge actions as right or wrong in accordance with whether they have good consequences. So you try to do what will have the best consequences for all of those affected. When it comes to food it means that obviously you look not only at whether you enjoy what you're eating but also what you're contributing to and supporting with your food purchases. That's of particular concern where you're contributing to or supporting a system that abuses animals, that damages the environment, that's harmful to workers, and so on $^{12}$ (SINGER, 2006).

\footnotetext{
11 Especismo é uma ideia mais específica, é a opinião que humanos tipicamente têm. É uma atitude de preconceito ou de pré-julgamento contra seres que não são membros de sua espécie, e há uma tendência a ignorá-los ou a não nos interessarmos por eles. E obviamente o termo foi cunhado para fazer um paralelo com sexismo e racismo Eu não inventei o termo, vi em um pequeno livro escrito por um homem chamado Richard Ryder, que se interessava pelo uso de animais em experiências e pesquisas, cujo título era Victims of science. E, então, tenho usado esse termo com a sua permissão. Acho que ajudei a popularizar o conceito e o tornei filosoficamente mais preciso. Mas, creio que ele estava ali esperando para ser usado, pois a analogia entre racismo e especismo é bastante óbvia uma vez que você pensa sobre ela." (SINGER, 2014). 12 Ser um utilitarista significa que você julga as ações como certas ou erradas a dependendo das consequências positivas que elas eventualmente venham a ter. Então você tenta praticar o que traz mais consequências positivas para todos os que são afetados. Quando se trata de comida isso , obviamente, significa que você não escolhe apenas baseado no prazer que ela vai te trazer, mas também com o que você está contribuindo e apoiando ao comprar sua comida. Isso é particularmente preocupante quando você está contribuindo com um sistema que abusa dos animais, que danifica o meio ambiente, que é prejudicial aos trabalhadores, e assim em diante (tradução nossa).
} 
Para os benestaristas, a preocupação final é com o aumento do "conforto" que esses animais destinados ao uso humano teriam; como ter jaulas maiores por exemplo. Para os neobenestaristas, como é o caso de Singer, o bem-estar deve ser um caminho para se chegar à libertação animal. Deve haver, num primeiro momento, a preocupação com o bem estardesses animais. Peter Singer não desconsidera o costume social de exploração animal e considera improvável a ocorrência de uma mudança brusca de consciência. Seria preciso uma mudança "de dentro para fora".

To avoid inflicting suffering on animals - not to mention the environmental costs of intensive animal production-we need to cut down drastically on the animal products we consume. But does that mean a vegan world? That's one solution, but not necessarily the only one. If it is the infliction of suffering that we are concerned about, rather than killing, then I can also imagine a world in which people mostly eat plant foods, but occasionally treat themselves to the luxury offree range eggs, or possibly even meat from animals who live good lives under conditions natural for their species, and are then humanely killed on the farm ${ }^{13}$ (SINGER, 2006 apud FRANCIONE, 2007).

Singer não sugere a abstenção ao prazer, pelo contrário, ele entende que essa busca é saudável e natural ao ser humano. O que ele recomenda é que esse prazer, especificamente no tocante à alimentação, seja substituído. Ele sugere que as pessoas busquem substituir o sabor trazido pela carne por outras dietas que podem ser tão saborosas quanto, porém que ainda são inexploradas, como a busca por novos ingredientes e novas maneiras de se preparar uma receita vegana (SINGER, 2006).

\footnotetext{
13 Para evitar infligir sofrimento aos animais — fora os custos ambientais da produção animal intensiva - precisamos cortar drasticamente a quantidade de produtos animais que consumimos. Mas isso significa um mundo vegano? É uma solução, mas não necessariamente a única. Se é com o fato de infligir sofrimento que estamos preocupados, e não com o fato de matar, então eu também posso imaginar um mundo em que as pessoas consomem principalmente alimentos à base de plantas, mas de vez em quando se dão o luxo de comer ovos de aves criadas soltas, ou possivelmente até carnes de animais que vivem uma boa vida em condições naturais para suas espécies e depois são mortos humanitariamente na fazenda (tradução disponível em < http://www.anima.org.ar/libertacao/abordagens/o-luxo-da-morte.html>. Acesso em 11 mai.2015.
} 
Dessa maneira, o uso animal, de uma maneira geral, poderia ser facilmente substituído, sobretudo pelas famílias de classe média e alta. $\mathrm{O}$ acesso a novas tecnologias, alimentos e materiais permitiria tal mudança. $\mathrm{O}$ alimento de base animal poderia ser substituído por uma dieta vegana e pela complementação alimentar a base de vitaminas. Em relação ao vestuário, o uso de material sintético supriria o uso de couros e peles. Em relação à diversão, com a variedade de mídias disponíveis atualmente, o uso de animais para espetáculos seria ultrapassado e desnecessário.

Para os abolicionistas, essa mudança deve ser imediata. O sistema deveria mudar, cessando a exploração animal (REAGAN, 2006, p.72).

Em relação à extensão dos direitos aos animais não humanos, também constatamos divergências. Apesar de ambos considerarem a necessidade de proteção para todos os animais, eles divergem quanto à aquisição de direitos subjetivos pelas outras espécies.

Para Peter Singer, o ponto central de sua teoria é a capacidade de senciência.

\begin{abstract}
Se um ser sofre, não pode haver justificação moral para a recusa de tomar esse sofrimento em consideração. Independentemente da natureza do ser, o princípio da igualdade exige que o sofrimento seja levado em linha de conta em termos igualitários relativamente a um sofrimento semelhante de qualquer outro ser, tanto quanto é possível fazer comparações aproximadas. Se um determinado ser não é capaz de sofrer nem de sentir satisfação nem felicidade, não há nada a tomar em consideração É por isso que o limite da senciência (para usar o termo como uma abreviatura conveniente, ainda que não estritamente precisa, da capacidade de sofrer ou de sentir prazer ou felicidade) é a única fronteira defensável da preocupação pelo interesse alheio. Marcar esta fronteira com alguma característica como a inteligência ou a racionalidade seria marcá-la de modo arbitrário (1993, p.44).
\end{abstract}

Ser senciente, além de sentir dor e prazer, é ter a capacidade de buscar o prazer e se afastar da dor, bem como de associar eventos positivos e negativos no tempo. De acordo com estudos realizados por primatólogos, etólogos e psicólogos (SANTANA, 2006, p.61), ficou demonstrado que os grandes primatas ${ }^{14}$, possuem tais características (GORDILHO, 2011,164166). Portanto, o conceito de pessoa deve ser estendido para esses animais, garantindo, desta maneira, sua capacidade jurídica natural.

\footnotetext{
14 Dos estudos mencionados, foi criado um projeto internacional chamado Great Ape Project. A página eletrônica do projeto no Brasil pode ser acessada em <http://www.projetogap.org.br/>. Acesso em 11 mai. 2015.
} 
Com base na obra de Jeremy Benthan (p.6), que tratava em seu utilitarismo clássico da equação coletiva entre dor e prazer para se alcançar o mais efetivo bem estar social. Richard Ryder construiu a teoria do dorismo. Segundo ela seria a capacidade de sentir dor que diferenciaria os seres. Os estudos de Ryder chegaram às mãos de Singer na universidade de Oxford ${ }^{15}$. A partir desses estudos, Peter Singer acrescentou, além da capacidade de sentir dor, a noção de percepção de sua existência, criando o conceito de senciência ${ }^{16}$.

Para Tom Reagan, em contrapartida, todos os vertebrados deveriam ser sujeitos de direito já que possuem sistema nervoso e córtex cerebral bem desenvolvido. Apesar de pensar dessa maneira, ele entende que é preciso fazer um recorte em seus estudos que acabe restringindo o abolicionismo animal. Ele afirma que "são os direitos dos mamíferos e dos pássaros que defenderei, ao responder às objeções aos direitos dos animais [...]” (2006, p.74)

\subsection{TEORIAS HOLÍSTICAS}

Abordaremos as próximas três teorias, Teia da Vida, Hipótese de Gaia e Deep Ecology de forma integrada, pois, identificamos que as três têm um ponto em comum, uma visão holística da ecologia.

Diferentemente dos bem-estaristas e abolicionistas que, de forma menos ou mais ampla, se preocupam com a vida e bem estar dos animais, essas teorias levam em conta todos os seres vivos e até os não vivos. Por tanto, compilaremos tais teorias dentro de um paradigma que chamaremos de ecocentrismo.

Pela Hipótese de $\mathrm{Gaia}^{17}$, a terra é, por si só, um ser vivo e pulsante. Essa característica seria facilmente visível do espaço. James Lovelock, criador da teoria, constatou esse fato ao realizar estudos para a NASA nos anos 60 do século passado. Ao vermos a terra como observadores externos, teríamos a percepção imediata do planeta como um organismo vivo. A terra teria, por si só, um mecanismo autoregulador capaz de manter equilibradas e saudáveis todas as formas de vida e não apenas uma delas, no caso, o homem (SCHELP, 2006, p.1).

\footnotetext{
${ }^{15}$ Contato narrado na página oficial de Richard Ryder. Disponível em < http://www.62stockton.com/richard/speciesism.html>. Acesso em 11 mai. 2015

16 Essa concepção de Singer sobre a capacidade de sentir e, no caso dos grandes símios de perceber sua existência em relação ao tempo e ao espaço, vai de encontro à ideia de desein, ser/perceber a sí mesmo, de Heidegger que seria um atributo inerente aos humanos (SANTANA, 2006, p.59).

$17 \mathrm{O}$ termo Gaia foi utilizado como referência a Gaia, a deusa grega da terra.
} 
Lovelock fez parte de uma equipe multidisciplinar contratada pela NASA para estudar a viabilidade da existência de vida em marte. Durante seus estudos ele, ao invés de analisar exclusivamente os dados daquele planeta, percebeu que seria mais viável, primeiramente, compreender de que forma é possível a existência de vida na terra para usar nosso planeta como modelo e, posteriormente, verificar se as condições de Marte seriam propícias, com base nos dados retirados da Terra, à existência de vida.

Using our own planet as a model, we examined the extent to which simple knoledge of the chemical composition of the earth's atmosphere, when coupled with coupled with such readily accessible information as the degree of solar radiation and the presence of oceans as well as land masses on the Earth's surfasse, could provide evidence for life ${ }^{18}$ (LOVELOCK, 2000, p.6).

Ao realizar seus estudos, observou que existe um constante desequilíbrio energético na terra, como trocas de calor, conversão de gás carbônico em oxigênio etc., que seria o responsável pela vida na terra. Uma afirmação que seria contraditória num primeiro momento embasa sua teoria. É o desequilíbrio físico e bioquímico terrestre que propicia o equilíbrio da vida ${ }^{19} \mathrm{em}$ nosso planeta (LOVELOCK, 2000, p.32).

Para Fritjof Capra (1996), os diversos seres vivos e componentes inanimados da Terra estariam conectados pelo que ele chama de Teias. Essas teias seriam as responsáveis pelo pleno equilíbrio da terra. Para que uma proteção efetiva seja realizada, é necessário pensar na Terra como um todo e na repercussão que a "quebra" de um desses "fios" poderia causar para todo o sistema.

A ciência do século XX propiciou a possibilidade de mudança sobre a forma com que os objetos são estudados, buscando-se um "novo paradigma complexo, capaz de ampliar os horizontes das explicações científicas, tanto nas ciências físicas e biológicas como nas ciências sociais" (GUIMARÃES, 2014, p.22). Tradicionalmente, utilizamos o método dedutivo-analítico proposto por Descartes para realizar nossos estudos, ou seja, isolamos um objeto para tentar entender suas funções para posteriormente sua participação num contexto mais abrangente.

Os métodos científicos desenvolvidos no século passado demonstram que uma visão sistêmica pode ser mais efetiva. De acordo com essa metodologia, não devemos isolar o objeto para estudar suas propriedades pois a "análise significa isolar alguma coisa a fim de entendê-la;

\footnotetext{
18 Usando nosso próprio planeta como modelo, nós examinamos a extensão que o simples conhecimento sobre a composição química da atmosfera da Terra, quando comparada com informações prontamente acessíveis, tais quais o grau de radiação solar e a presença de oceanos e massa terrestre na superfície da terra poderia fornecer evidência de existência de vida (tradução nossa).

19 Quando nós falarmos apenas “equilíbrio" neste trabalho, é a esta espécie que estaremos nos referindo
} 
o ensamento sistêmico significa colocá-la no contexto de um todo mais amplo" (CAPRA, 1996, p.31).

Ao usarmos o pensamento sistêmico, constatamos que

[...] a física quântica mostra que não podemos decompor o mundo em unidades elementares que existem de maneira independente. Quando desviamos nossa atenção dos objetos macroscópicos para os átomos e as partículas subatômicas, a natureza não nos mostra blocos de construção isolados, mas, em vez disso, aparece como uma complexa teia de relações entre as várias partes de um todo unificado (CAPRA, 1996, p.32).

Essa "rede de teias" seria tão complexa que, apesar de permitir a compreensão de alguns fenômenos, o homem nunca conseguirá prever todos os acontecimentos, todas as consequências de seus atos e dos fatos da natureza pois "algo pode ocorrer ou não ocorrer e todo o resto permanecer na mesma” (WITTGENSTEIN, 1968, p.55).

\begin{abstract}
O efeito borboleta foi descoberto no começo da década de 60 pelo meteorologista Edward Lorenz, que desenhara um modelo simples de condições meteorológicas consistindo em três equações não-lineares acopladas. Ele constatou que as soluções das suas equações eram extremamente sensíveis às condições iniciais. A partir de dois pontos de partida praticamente idênticos, desenvolver-se-iam duas trajetórias por caminhos completamente diferentes, o que tornava impossível qualquer previsão a longo prazo (CAPRA, 1996, p.104).
\end{abstract}

A teoria do caos reforça o nosso argumento em prol da complexidade e conectividade ecológica. Estudos analíticos tendem a isolar um objeto em uma situação considerada "ideal", como a “Condição Normal de Temperatura e Pressão - CNTP” , amplamente utilizado em simulações físicas, mas esse tipo de evento não ocorre na natureza. A atmosfera, por exemplo, "is not a controlled laboratory experimente; if we disturbe it and then observe what happens, we shall never know what would have happened if we had not disdurbed it ${ }^{20}$ " (LORENZ, 1972, p.1).

Para uma compreensão mais adequada das interações naturais, seria necessário a realização da proteção dessas interações,

Para o sucesso dessa abordagem holística, temos que tentar nos afastar ao máximo da visão cartesiana de especializar, reduzir os eventos e as coisas em pequenos objetos de estudo. A natureza funciona de forma global, não há como compreender seus eventos sem relacioná-los com outros fatos que estejam ocorrendo simultaneamente ou que já ocorreram, ainda que esses

\footnotetext{
20 [...] não é um experimento controlado em laboratório; se nós a provocarmos e observarmos o que acontece, nós nunca saberemos o que teria ocorrido se não tivéssemos realizado tal perturbação (tradução nossa).
} 
fatos sejam objetos de outra ciência que não a de que somos especialistas. O ideal é que haja uma visão transdisciplinar sobre o objeto de estudo escolhido, buscando estudos realizados por profissionais de áreas diversas de sua formação para tentar se compreender ao máximo essa complexidade. Caso isso não seja possível, que seja realizado um estudo multidisciplinar para, unindo diversas especialidades, seja possível tentar uma abordagem mais generalizante.

\begin{abstract}
Acontece que o problema da complexidade não é o da completude, mas o da incompletude do conhecimento. Num sentido, o pensamento complexo tenta dar conta daquilo que os tipos de pensamento mutilante se desfaz, excluindo o que eu chamo de simplificadores e por isso ele luta, não contra a incompletude, mas contra a mutilação. Por exemplo, se tentamos pensar no fato de que somos seres ao mesmo tempo físicos, biológicos, sociais, culturais, psíquicos e espirituais, é evidente que a complexidade é aquilo que tenta conceber a articulação, a identidade e a diferença de todos esses aspectos, enquanto o pensamento simplificante separa esses diferentes aspectos, ou unifica-os por uma redução mutilante. Portanto, nesse sentido, é evidente que a ambição da complexidade é prestar contas das articulações despedaçadas pelos cortes entre disciplinas, entre categorias cognitivas e entre tipos de conhecimento. De fato, a aspiração à complexidade tende para o conhecimento multidimensional. Ela não quer dar todas as informações sobre um fenômeno estudado, mas respeitar suas diversas dimensões: assim como acabei de dizer, não devemos esquecer que o homem é um ser biológico-sociocultural, e que os fenômenos sociais são, ao mesmo tempo, econômicos, culturais, psicológicos etc. (MORIN, 2005, p.176-177).
\end{abstract}

A junção da essência da teoria do caos de que um evento específico alteraria o todo vai de encontro ao dito por Ludwig Wittgenstein; "a totalidade dos fatos determina, pois, o que ocorre e também tudo o que não ocorre" (1968, p.55).

Para Edward Lorenz, um efeito específico pode mudar o todo, já para Wittgenstein não há, necessariamente, essa relação. Apesar de haver essa divergência, ambos concordam que é observando o todo que podemos entender os fatos. As múltiplas relações naturais são tão complexas que para ambos é improvável que o homem possa identificar e antecipar todos esses eventos.

Essa ideia de generalidade e de imprevisibilidade é coerente com a teoria de Capra, já que a biosfera seria tão complexa que não haveria como ter certeza do impacto de uma ação sobre o meio ambiente. Apesar disso, através dessa cosmovisão, é possível chegar o mais próximo possível desse intento. É preciso ter uma visão transdisciplinar da ecologia para tentar prever os fatos naturais e manter o equilíbrio da Terra; por isso a necessidade do abandono do paradigma antropocêntrico

Já a teoria da Deep Ecology, elaborada por Arne Naess (NELSON, p.1), distingue a ecologia rasa da profunda. "Ecologically responsible policies are concerned only in part with pollution and resource depletion. There are deeper concerns which touch upon principles of diversity, 
complexity, autonomy decentralization, symbiosis, egalitarism, and classlessness ${ }^{21}$ " (NAESS, 2008 p.95).

A ecologia rasa seria aquela preocupada com os problemas ambientais imediatos, notadamente com um viés antropocêntrico. Já a ecologia profunda, por sua vez, preocupa com todo o sistema e de forma mediata. Ela analisa profundamente os problemas ambientais e busca a melhor forma de promover o equilíbrio do sistema e garantir o bem-estar humano. Para tanto, insta a realização de um estudo transdisciplinar das diversas correntes de pensamento como a ética, a sociologia e a política, para, trabalhando em conjunto, formular uma ecosofia, uma filosofia voltada à ecologia, que seja efetiva sob o ponto de vista ecológico e normativo, garantindo, assim, um equilíbrio salutar entre o homem, as demais espécies de vida e o meio nas quais estão inseridas (NAESS, 2008, p.100).

Podemos perceber mudanças em relação aos métodos sugeridos pelos representantes de cada corrente, mas parece claro que há um alargamento da "sombra" de proteção dos objetos tutelados, sendo, muitas vezes, conferido até o status de sujeito ${ }^{22}$. Independentemente das divergências, essa ampliação da proteção ambiental tende a buscar a estabilidade de todo o sistema indo além do conceito de desenvolvimento sustentável que visa, apenas, garantir aos seres humanos das próximas gerações a possibilidade de desfrutar os benefícios trazidos pela natureza. Percebemos, ainda, uma visão de superioridade do homem perante os outros seres viventes e ao meio no qual está inserido.

\section{CONCLUSÃO}

Demonstramos um resumo da evolução da abordagem internacional das questões ambientais através dos principais tratados, verificando que o pós-guerra abriu caminho para a discussão internacional sobre novos temas que não relacionados a segurança internacional. Com o fim da guerra fria, houve um reforço aos estudos referentes aos "novos temas" pois o ambiente hostil entre as duas grandes potências, EUA e URSS, já não existia mais.

\footnotetext{
21 Políticas ecologicamente responsáveis se preocupam apenas parcialmente com a poluição e o esgotamento de recursos. Existem preocupações mais profundas que tratam dos princípios da diversidade, da complexidade, da autonomia descentralizada, da simbiose, da equidade e da não divisão em classes (tradução nossa).

22 Como no caso da corrente abolicionista (item 3.1).
} 
Com a multipolarização, novos atores puderam participar do processo decisório e os países emergentes ocuparam cada vez mais lugares nos fóruns internacionais. Esse processo foi de grande importância, pois é justamente nesses países que estão concentrados as grandes reservas de biodiversidade do planeta. Sendo assim, era um imperativo que tais países participassem das discussões sobre o tema.

Em relação a preservação da biodiversidade, podemos constatar duas grandes preocupações, uma delas está relacionada ao desenvolvimento desses países e de suas populações, até porque, como já afirmamos, são os países em desenvolvimento que possuem as maiores reservas de biodiversidade. Passou-se a discutir de que forma poderia haver a preservação ambiental, o uso desses recursos e, simultaneamente, sua preservação.

A outra, ocupava-se da preservação em si. De que forma evitar que a atividade humana impactasse ainda mais na biosfera.

Ambos os interesses são relevantes, mas por conta do paradigma antropocêntrico dominante no mundo ocidentalizado, a primeira preocupação teve um destaque bem maior do que a segunda, demonstrando a preocupação decorrente dessa disparidade no decorrer do trabalho. Não nos colocamos contra o desenvolvimento humano, muito pelo contrário, ele é essencial em várias vertentes, sobretudo, já que este é o tema central deste trabalho, na tomada de consciência da importância do meio ambiente e de sua preservação. É imperativo educar as comunidades sobre o tema, mas a tarefa se torna muito mais complexa quando a fome e o desabrigo preocupam milhões de pessoa. Como pensar numa sobrevivência global, se milhões estão se preocupando com a própria sobrevivência?

Além do mais, muitos projetos associados ao desenvolvimento humano estariam, consequentemente, protegendo o meio ambiente, como é o caso do fornecimento adequado de saneamento básico. Ao descartar adequadamente os dejetos, a saúde humana seria protegida, enquanto haveria uma redução da poluição ambiental concomitante.

Apesar de reconhecer a importância do desenvolvimento humano, fizemos questão de criticar explicitamente a colocação em segundo plano da preservação ambiental em si mesmo, sobretudo nos fóruns criados especificamente com essa finalidade. O ideal seria, ao tratar de desenvolvimento sustentável, colocar ambos os temas no mesmo patamar e ao tratar de proteção da biodiversidade, debater prioritariamente a sua proteção de per si. Da mesma maneira, se uma convenção tem fins econômicos, esses devem ter prioridade nos debates. 
A economia e as questões ligadas a ela, como o desenvolvimento, são de grande relevância, mas os temas ambientais não podem ser preteridos, como vem ocorrendo, conforme a observação dos objetivos dos tratados mais recentes sobre o tema. Temos reconhecido que a questão ambiental é urgente, mas temos prorrogado a aplicação de soluções práticas. Devemos abordar cada vez mais o tema sob pena de virarmos meros expectadores da degradação ambiental, como "anjos neutros"23.

Após um breve histórico, passamos a analisar as principais correntes doutrinárias que levariam a mudança do paradigma antropocêntrico para o ecocêntrico, estudando as correntes animalistas e holísticas, destacando, entre as existentes, as que entendemos serem mais relevantes.

Ao nosso ver, as teorias holísticas possuem a melhor fundamentação, pois não se restringem a apenas uma categoria de seres destinados a uma proteção. Elas tentam demonstrar a importância de um meio ambiente equilibrado e de como todo o sistema ecológico se beneficiaria com essas práticas. $\mathrm{O}$ homem, assim como os demais seres, para sobreviver, causa, necessariamente, um dano ao meio ambiente, mas esse dano deve ser controlado para não romper o equilíbrio da terra. Ao pensar dessa maneira, não apenas os homens e os animais serão protegidos, mas toda a biosfera. As teorias propostas por Capra, Naess e Lovelock têm esse ponto em comum.

Dentre as teorias apresentadas, a proposta de Capra nos parece a com maior possibilidade de auxiliar na emersão de um paradigma ecológico, pois propõe metas viáveis. O ponto central apontado por Capra é que, antes de uma mudança de mentalidade, de uma mudança racional humana, é preciso modificar (e em muitos casos implementar) a educação ecológica, além de utilizar recursos financeiros para conseguir fins mais imediatos. Uma educação ecológica de qualidade deve demonstrar que os atos humanos têm consequências para o equilíbrio de toda a biota. Após essa mudança forçada pela educação e pela economia, ocorrerá um aumento da consciência social relativa à importância do equilíbrio ambiental.

Demonstramos de que maneira ocorreu a emergência do paradigma moderno e suas consequências para a sociedade e para o direito. Constatamos, ainda, que existem diversas correntes teóricas que demonstram a insuficiência desse paradigma em atender às demandas sociais do século XXI, bem como sua insustentabilidade, uma vez que os recursos naturais estão

\footnotetext{
23 Existiu uma estória medieval que afirmava que os anjos que não tomaram partido nem de Deus nem de Lúcifer quando de sua queda do Paraíso foram condenados à vagar eternamente no Limbo. Não tinham permissão de entrar no Céu por não terem defendido seu criador, tampouco eram aceitos no inferno, pois o Diabo não permitia sua entrada. Trata-se de um mito criado para demonstrar que a inação perante injustiças também é capaz de condenar até as almas mais puras à danação eterna (ALIGHIERI, 2011,p.49).
} 
se esgotando, levando ao desequilíbrio da Terra. Junto com esse desequilíbrio, passamos a constatar, ainda que de forma modesta, a tomada de consciência social sobre o tema fora dos meios acadêmicos. Apresentamos os mais importantes instrumentos do direito internacional que tratam da proteção ambiental; num primeiro momento restrita aos interesses humanos, mas evoluindo, cada vez mais, para uma proteção ecológica como fim em si mesmo.

Diante das novas correntes doutrinárias apresentadas, entendemos que as teorias holísticas têm grande importância no papel fundante de um novo paradigma ecológico, já que não se restringem à apenas um ou alguns setores de proteção da vida.

Os sinais da mudança gradual de paradigma podem ser notados em todas as grandes revoluções científicas da humanidade. Se olharmos os estudos de Copérnico, Galileu e Darwin, por exemplo, mudaram a forma do homem de praticar as ciências e de observar sua relação com o mundo natural, mudando inclusive, historicamente, as eras em que o homem se coloca no mundo, como no renascimento ${ }^{24}$, por exemplo. Observamos que, nessas grandes descobertas científicas, o ponto central sempre era a mudança da visão que o homem tinha de si mesmo em relação ao universo. Copérnico demonstrou que a Terra girava em torno do Sol, e não o contrário como sempre se acreditou. Galileu foi acusado de heresia por ter difundido nos meios acadêmicos o heliocentrismo. Darwin, por sua vez, sustentou que o homem é fruto de uma série de evoluções naturais e adaptativas que o fez chegar ao estado atual, e não que a Terra teria sido criada para o deleite humano. O mundo passaria a ser visto cada vez mais como um "desequilíbrio equilibrado" de reações e relações que proporcionam o seu sustento. Desequilibrado, pois, das diferenças entre pressão, temperatura, etc., é que surge a energia necessária para seu sustento; equilibrado, pois é dessa energia que é possível a ocorrência da convivência harmoniosa entre todos os seres vivos e a sua interação com o meio em que vivem.

A história demonstra que esse processo em direção à mudança de paradigma está ocorrendo. Numa primeira fase, ocorre a dúvida quanto às mudanças propostas, numa segunda fase o paradigma tenta operar mudanças dentro do próprio sistema para fazer as mudanças sociais se adaptarem as suas regras propostas. Numa última, o padrão adotado é considerado insustentável

\footnotetext{
24 Na Idade Média, apesar da visão antropocêntrica, o homem estava explicitamente colocado numa situação de inferioridade a Deus. “Com o fim da Idade Média [...] o 'Renascimento' vai promover o retorno do homem ao centro das preocupações artísticas e filosóficas, preparando as bases para o antropocentrismo moderno" [...]É importante notar que o humanismo renascentista não tinha um sentido de humanitarismo, enquanto tendência a agir com humanidade, ele apenas pretendia trazer o homem de volta ao centro das preocupações filosóficas, lugar este que fora ocupado por Deus durante o pensamento medieval. (SANTANA, 2006, p.51).
} 
e há o rompimento do paradigma anterior e surgimento de um novo. Ao nosso ver, estamos na segunda fase. Os acontecimentos políticos e sociais que estão por vir, como o aquecimento global, protestos contra a fome, poluição, etc. é que determinarão quando essa última fronteira será rompida e ocorrerá a emergência do paradigma ecológico em detrimento do antropológico.

\section{REFERÊNCIAS}

ACCIOLY, Hildebrando; SILVA, G. E. do Nascimento e; CASELLA, Paulo Borba. Manual de Direito Internacional Público. 20.ed. São Paulo: Saraiva, 2012.

ALIGHIERI, Dante. A Divina Comédia. São Paulo: Landmark, 2011.

ANNAN, Kofi. Promoting Sustainable Development. Nova York: UM, 2002. Disponível em < http://www.un.org/press/en/2002/sgsm8239.doc.htm>. Acesso em 27 abr. 2015.

BARRETO, Myrna Suyanny. Heráclito na Filosofia do Jovem Nietzsche. 2011. $71 \mathrm{f}$. Dissertação (Mestrado em Filosofia) - Universidade Federal do Rio Grande do Norte, Natal, 2011. Disponível em:

<http://www.cchla.ufrn.br/ppgfil/mestrado/dissertacoes/myrna_suyanny_barreto.pdf $>$. Acesso em: 11 mai. 2015.

BENTHAN, Jeremy. An Introduction to the Principles of Moral and Legislation.

Disponível em < http://www.earlymoderntexts.com/pdfs/bentham1780.pdf >. Acesso em 11 mai. 2015.

BEZERRA, Paulo Cesar Santos. Temas Atuais de Direitos Fundamentais. 2.ed. Ilhéus: Editus, 2007.

BOLTON, Rodrigo Karmy. Bioética y el Islam. Acta Bioethica, San Tiago, Ano XVI, n.1, p.25-30, 2010. Disponível em : < http://actabioethica.cl/docs/acta21.pdf>. Acesso em: 13 mai. 2015 .

BYINGTON, Carlos Amadeu Botelho. Psicologia Simbólica Junguiana: a viagem de humanização do cosmos em busca da iluminação. São Paulo: Linear B, 2008.

CAPRA, Frijot. A Teia da Vida: uma nova compreensão científica dos sistemas vivos. São Paulo: Cultrix, 1996.

CERVI, Taciana Marconatto Damo. O Direito Ambiental e a Ética da Cidadania na Transição Paradigmática. Rio de Janeiro: GZ, 2012.

DESCARTES, René. Discurso do Método. 2.ed. São Paulo: Martins Fontes, 2001.

FRANCIONE, Gary L.The "Luxury" of Death. 2007. Disponível em < http://www.abolitionistapproach.com/peter-singer-the-luxury-of-death/\#.VUwITSHBzGc >. Acesso em 09 mai. 2015. 
GARRAFA, Volvei; PORTO, Dora. Bioética, Poder e Injustiça: por uma ética de intervenção. In: GARRAFA, Volnei; PESSINI, Leo. Bioética: poder e injustiça. São Paulo: Loyola, 2003.

GOMES, Luiz Flávio. Revolução Francesa. Disponível em <http://www.youtube.com/watch?v=ssJiWqOb6IM>. Acesso em 23 nov. 2013.

GOMES, Sebastião Valdir. Direito Ambiental Brasileiro. Rio de Janeiro: Síntese, 1999.

GORDILHO, Heron José de Santana. Direito Ambiental Pós-Moderno. Curitiba: Juruá, 2011.

GUIMARÃES, Nina Vasconcelos. Alpinismo Sistêmico: dos primórdios cartesianos às falácias construcionistas. In: Autoridade e Autonomia em Tempos Líquidos: a teoria sistêmica na contemporaneidade. Belo Horizonte: Ophicina, 2014.

HOBSBAWM, Eric. Era dos Extremos: o breve século XX. 2.ed. São Paulo: Companhia das Letras, 2010.

LAGO, André Aranha Corrêa do. Estocolmo, Rio, Joanesburgo: o Brasil e as três conferências ambientais das Nações Unidas. Brasília: Funag, 2007.

LORENZ, Edward N. Predictability; Does the Flap of a Butterfly's Wing in Brazil Set Off a Tornado in Texas? Cambridge: American Association for the Advancement of Science, 1972. Disponível em < http://eaps4.mit.edu/research/Lorenz/Butterfly_1972.pdf>. Acesso em 07 mai. 2015.

LOVELOCK, James. GAIA: a new look at life on earth. Nova York: Oxford, 2000.

MONTIBELLER FILHO, Gilberto. Ecodesenvolvimento e Desenvolvimento Sustentável: conceitos e princípios. Disponível em:

$<$ https://periodicos.ufsc.br/index.php/economia/article/download/6645/>. Acesso em 23 nov. 2013.

MORAES, Antônio Carlos Robert. Geografia: pequena história crítica. São Paulo: Annablume, 2005.

MORIN, Edgar. Ciência com Consciência. 8.ed. Rio de Janeiro: Bertrand, 2005.

MUNIR. Sheikh David. Bioética e religiões. In: Bioética \& Religiões. Lisboa: CNECV/FLAD, 2013. Disponível em: <http://www.cnecv.pt/admin/files/data/docs/1415190101_Livro\%20bioetica_16_Bioetica\%20 e\%20Religioes.pdf >. Acesso em: 13 mai. 2015.

NAESS, Arne. The shallow and the deep, long-range ecology movement. A summary. Inquirity: an interdiciplinary jornal of philosophy. 2008. Disponível em <http://dx.doi.org/10.1080/00201747308601682>. Acesso em 11 mai. 2015. 
NELSON, Michael P. Deep Ecology. Disponível em < http://www.uky.edu/OtherOrgs/AppalFor/Readings/240\%20-\%20Reading\%20\%20Deep\%20Ecology.pdf>. Acesso em 06 mai. 2015.

PAIXÃO, Rita Leal. Experimentação Animal: razões e emoções para uma ética. 2001. 149f. Tese (Doutorado em Saúde Pública) - Fundação Oswaldo Cruz - FIOCRUZ, Rio de Janeiro, 2001. Disponível em: < http://portalteses.icict.fiocruz.br/pdf/FIOCRUZ/2001/paixaorld/capa.pdf>. Acesso em: 16 mai. 2015.

PELIZZOLI, M.L. A Emergência do Paradigma Ecológico: reflexões ético-filosóficas para o século XXI. Petrópolis: Vozes, 2004.

POMPEU, Gina Vidal Marcílio; HOLANDA, Marcus Mauricius. Desenvolvimento, Trabalho e Renda: instrumentos de efetivação da redução da pobreza extrema e da fome, escopo primeiro dos objetivos de desenvolvimento do milênio. In: Direito Internacional em Expansão. Wagner Menezes et al (Org.). Belo Horizonte: Arraes, 2014.

POTTER, Van Rensselaer; POTTER, Lisa. Global Bioethics: converting sustainable development to global survival, 1995. Disponível em: < http://www.ippnw.org/pdf/mgs/2-3potter.pdf>. Acesso em: 16 mai. 2015.

REAGAN, Tom. Jaulas Vazias: encarando o desafio dos direitos animais. Porto Alegre: Lugano, 2006.

REIS, Simony Lopes da Silva. O Direito Ambiental como Regulador do Modelo de Desenvolvimento Atual. In: Direito Ambiental, Conflitos Socioambientais e Comunidades Tradicionais. Org. ROCHA, Julio Cesar de Sá; SERRA, Ordep. Salvador: Edufba, 2015.

SANTANA. Heron José de. Espírito Animal e o Fundamento Moral do Especismo. Revista Brasileira de Direito Animal, Salvador, Ano I, n.1, p.37-65, 2006. Disponível em < http://www.portalseer.ufba.br/index.php/RBDA/article/viewFile/10240/7296>. Acesso em 14 mai. 2015.

SANTOS, Milton. Metamorfoses do Espaço Habitado: fundamentos teóricos e metodológicos da Geografia. São Paulo: Hucitec, 1988.

SCHELP, Diogo. A Vingança de Gaia. Disponível em < http://www.ia.ufrrj.br/ppgea/conteudo/T2-

5SF/Claudio/A\%20vingan\%E7a\%20de\%20Gaia.pdf>. Acesso em 07 mai. 2015.

SCHRAMM. Fermin Roland. Bioética e Biossegurança. Disponível em < http://www.portalmedico.org.br/biblioteca_virtual/bioetica/ParteIIIbioseguranca.htm>. Acesso em 05 mai. 2015.

SIMÕES, Ricardo Santos; JÚNIOR, Luiz Kulay; BARACAT, Edmund Chada. Importância da Experimentação Animal em Ginecologia e Obstetrícia. Revista Brasileira de Ginecologia e Obstetrícia, São Paulo, Ano VII, n.33, p.119-122, 2011. Disponível em: < 
http://www.scielo.br/pdf/rbgo/v33n7/a01v33n7.pdf>. Acesso em: 13 mai. 2015.

SINGER, Peter. Chew the Right Thing, 2006. Disponível em

<http://www.motherjones.com/politics/2006/05/chew-right-thing>. Acesso em 09 mai. 2015.

SINGER, Peter. Ética Prática. Lisboa: Gradiva, 1993.

SINGER, Peter. Filosofia é uma Forma de Vida, 2014. Disponível em

http://www.fronteiras.com/entrevistas/filosofia-e-uma-forma-de-vida-1424806465. Acesso em 07 mai. 2015.

SPINOZA, Benedictus de. Ética. Belo Horizonte: Autêntica, 2009.

WITTGENSTEIN. Ludwig. Tractatus Logico-Philosophicus. São Paulo: USP, 1968.

UN. Convention on Biological Diversity. Rio de Janeiro: CNUMAD, 1992. Disponível em < http://www.cbd.int/doc/legal/cbd-en.pdf>. Acesso em 27 abr. 2015.

UN. Declaração Universal sobre Bioética e Direitos Humanos. Lisboa: UNESCO, 2006. Disponível em < http://unesdoc.unesco.org/images/0014/001461/146180por.pdf>. Acesso em 26 abr. 2015.

UN. Introducing UNESCO. Disponível em < http://en.unesco.org/about-us/introducingunesco>. Acesso em 26 abr. 2015.

UN. Manual de la Conferencia General. Paris: UNESCO, 2002. Disponível em < http://unesdoc.unesco.org/images/0012/001255/125590s.pdf>. Acesso em 26 abr. 2015. 